\title{
食肉タンパク質酵素加水分解物のラット 血漿コレステロール上昇抑制効果
}

\author{
森松文毅* $・$ 木村修一** \\ Hypocholesterolemic Effect of Partial Hydrolyzates of \\ Pork Meat in Rats \\ Fumiki Morimatsu* and Shuichi Kimura** \\ ${ }^{*}$ Research and Development Center, Nippon Meat Packers INC, \\ Yoshida-cho, Shizuoka 421-03 \\ ** Laboratory of Nutrition, Faculty of Agriculture, Tohoku University \\ Amamiya-cho, Aoba-ku, Sendai, Miyagi 981
}

\begin{abstract}
It is well known that dietary vegetable proteins lower a level of plasma cholesterol more than animal proteins. The partial hydrolyzates of soybean protein have been shown to have possible hypocholesterolemic effects. In this study, hypocholesterolemic effects of partially hydrolyzed pork meat (PHPM) was examined in cholesterol-fed rats. The effects of pork meat and PHPM on plasma cholesterol, triglyceride, phospholipid, lipoproteins and free amino acids were determined. Plasma cholesterol decreased in rats fed PHPM, more than rats fed intact pork meat. Among the proteases examined, papain was most efficacious and plasma cholesterol became significantly lower by increasing the amount of protease. Rats fed an amino acid mixture prepared by acid hydrolysis did not show reduced level of cholesterol. Plasma free amino acid pattern of rats fed PHPM was similar to that fed soybean protein. PHPM thus apppears to exert a hypocholesterolemic effect depending on peptides in hydrolyzed pork meat. Based on the present results, it should be possible to prepare meat products having hypocholesterolemic effects.

(Received Sep. 6, 1991)
\end{abstract}

高コレステロール血症は冠動脈性心疾患の危険因子て あり ${ }^{1)}$ ，血漿コレステロール（chol）濃度は食䬣タンパ ク質の種類や量によって变動することが報告されてい る $^{23)}$. 一般に植物性タンパク質に比べ動物性タンパク 質で血獎 chol 濃度は高值を示すことはよく知られてい $3^{4) 52}$ が，カゼインと分離大豆タンパク質に関しての比 較研究が大半を占め, 豚肉タンパク質についての検討は あまりなされていない，食飰タンパク質による血獎・血 清 chol 濃度の変動については, その構成アミノ酸によ る影響が最も多く検討されてきだり?，しかし近年，食 餌タンパク質のタンパク質分解醉贲加水分解ペプチドの
血獎 chol 濃度に対する効果も検討されている．菅野ら は, 分離大豆タンパク質のタンパク質分解酵素加水分解 物 (以下, 酵素加水分解物) 中の不溶性高分子画分加, 大豆タンパク質よりあ血清 chol 濃度の上昇を抑制する ことを報告している ${ }^{8) \sim 10)}$ ．本研究では豚肉の酵素加水 分解物が分離大豆タンパク質と同様の血獎 chol 上昇抑 制効果を有するか否かをラットを用いて検討した。まず 豚肉を各種のタンパク質分解酵素で加水分解した場合の 血㢡 chol 濃度の変動について検討し, 次にその効果が 豚肉由来のペプチドに依存していることを調べるために， 加水分解の程度による影響と，豚肉のアミ，酸組成に調

*日本八么(株) 技術研究所（广421-03 静岡県榛原郡吉田町大幡 350-3）

** 東北大学農学部（テ981 宮城県仙台市青葉区堤通雨宮町 1-1） 
整したアミノ酸混合物の効果について実験した，最後に 大豆タンパク質との比較検討を行った。

\section{実 験 方 法}

\section{1. 実験動物およひ飼料組成}

実験動物として 4 週令の雄性 Wistar 系 ST ラット を市販固形飼料（船橋農場(株)・F 2) で 1 週間予備鸰 育した後に 3 回の実験に供した：いずれの奏験とも，ラ ットは一群 5 匹として 3 ないし 4 群を設け， 3 週間の飼 育実験を行った. Table 1 にタンパク質源の違いによ る実験群と実験笥料組成を示した．実験食は実験 1 では タンパク質源として豚背最長筋を細切し，へキサンで脱 脂した後に凍結乾燥したものを調製した（以下 MP 群 上呼ぶ）ささらにこの凍結乾燥脱脂豚肉に 4 倍容の水を 加えたのちペプシン（Sigma），トリプシン（和光純薬） およびパパイン（和光純薬）をそれぞれタンパク質 $1 \mathrm{~g}$

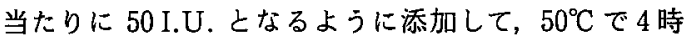
間酵素処理をおこなった（それぞれ PE 群，TR 群， $\mathrm{PA}$ 群と呼ぶ). 加水分解時の $\mathrm{pH}$ は 6.0 で, その後の

Table 1 Composition of experimental diets $(\%)$

\begin{tabular}{lrrr}
\hline \hline \multicolumn{1}{c}{ Ingredients } & Exp. 1 & Exp. 2 & Exp. 3 \\
\hline Corn starch & 62.05 & 72.05 & 72.05 \\
Lard & 5.00 & 5.00 & 5.00 \\
Protein $^{\mathrm{a})}$ & 20.00 & 10.00 & 10.00 \\
Vitamin mix $^{\mathrm{b})}$ & 2.00 & 2.00 & 2.00 \\
Mineral mix $^{\mathrm{c})}$ & 4.00 & 4.00 & 4.00 \\
Sodium chloride & 0.70 & 0.70 & 0.70 \\
Cellulose powder $_{\text {Cholesterol }}$ & 5.00 & 5.00 & 5.00 \\
Sodium cholate & 1.00 & 1.00 & 1.00 \\
\hline
\end{tabular}

a) Protein source was defatted pork meat (MP), pepsin hydrolyzed pork meat (PE), trypsin hydrolyzed pork meat (TR) and papain hydrolyzed pork meat (PA) in experiment $1, \quad 0.1 \%$ papain hydrolyzed pork meat (0.1 PA), $2.0 \%$ papain hydrolyzed pork meat (2.0 PA) and amino acids mixture (AA) in experiment 2 and defatted pork meat (Control), papain hydrolyzed pork meat (PA), soybean protein (SOY) in experiment 3.

b) Oriental's vitamin mixture

c) Harper's salt mixture without sodium
$\mathrm{pH}$ 調整は行わず，それぞれの酵素処理を実施後，全量 を涷結乾燥した.これらの酵素処理豚肉を未処理豚肉と

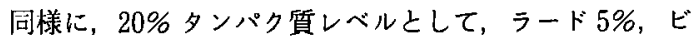
タミン混合（USP-17：船橋農場）2\%，ミネラル混合 (USP-17：船橋農場）4\%，セルロースパウダー5\%, 及びコレステロール付加食としてコレステロール $1 \%$ ， コール酸ナトリウム $0.25 \%$ を混合してコーンスターチ で $100 \%$ として実験食を調製した．実験 2 でのタンパク 質源としてはコントロールとして㬰験 1 で用いた逨結乾 燥豚肉（MP 群）の他に、これを0.1\%(50 I.U/g 夕 ンパク質）及び $2.0 \%$ (1000 I.U/g タンパク質)のパ パインで $50^{\circ} \mathrm{C} ， 4$ 時間醭素処理を抢こなったすの(0.1 PA 群，2.0 PA 群)，さらに凍結乾燥豚肉を真空減圧 下で酸加水分解してアミノ酸としたもの（AA 群）の 4 種類を作成した。これらのタンパク質源の窒素含有量 を等しくなるように調整して $10 \%$ タンパク質レベルと して実験 1 と同様の飼料を作成した．実験 3 では凍結乾 燥豚肉 (MP 群)，0.1\%パパイン処理豚肉 (PA 群) の他に, 分離大豆タンパク質 (SOY 群, フジピュリナ ープロテイン)をタンパク質源として飼料を作成した。 各実験ともナトリウムについては，豚肉加らの持ち込み， 豚肉酸加水分解後の中和による添加などにより大きく異 なるので，ミネラル混合には含まないようにし，食塭と して単独で添加するようにした，飼料は每日交換し，飲 料水之共に自由摄取させた。動物飼育室は室温 $25^{\circ} \mathrm{C}$,

湿度 $50 \pm 5 \%$ に保ち，12 時間ごとの明暗サイクル（午 前 8 時点灯，午後 8 時消灯）に調整した。

\section{2. 実呀飼料の各形態別窒素分布}

実験 1 及び 2 で使用した実験䬰料の各形態別の窒素分 布について分析した．総窒素量はケルダール法にて測定 した．水溶性窒素は 10 倍容の水で抽出後, 滤別して滤 液中の窒素をヶルダール法にて測定した。 ペプチド・ア ミノ態窒素 ${ }^{11)}$ は上の滤液にトリクロル酢酸 (片山化学 (株)）を加えて，10\%トリクロル酶酸濃度として $40^{\circ} \mathrm{C}$ で 20 分間保温後沈涮を除去して滤液中の窒素を定量し た．さらに同様に上の滤液を $12 \%$ トリクロル酢酸濃度 とした後遠心分離して上清の遊離アミノ酸を分析し，そ の総量をアミノ態窒素とした.

\section{3. 血漿脂質成分の分析}

実験期間中は体重，飼料㩒取量を毎日 1 回測定し，飼 育試験後，動物は 12 時間絶食してェーテル麻醉下で開 腹し，腹部大動脈より採血して常法により血漿を調製し た。血䈨中の総 chol $(\mathrm{T}-\mathrm{Ch})$, 遊離 $\mathrm{chol}(\mathrm{F}-\mathrm{Ch})$, トリグリセリト（TG）およびリン脂質（PL）は和光 
純薬工業(株) の各定量キットを用いて酵素法により测 定した.

\section{4. 血漿リポタンパク質分析}

日立超遠心機 HIMAC CP $100 \mathrm{H}$ を用いて段階的分 画浮上法により血漿りポタンパク質を分画した ${ }^{22}$ ．即ち 密度別に chylomicron 及び very low density lipoproteins (VLDL, $d<1.006$ ), low density lipoproteins (LDL, $1.006<\mathrm{d}<1.063$ ), high density lipoproteins (HDL, $1.063<\mathrm{d}<1.225)$ の各リポタンパク 質に分画し、レシチンーコレステロール・リポソームを スタンダードとして総 chol を测定した。

\section{5. 血䠌遊離アミノ酸分析}

遊離アミノ酸は血㢡をトリクロル酢酸で除タンパクし
たのち島津製作所(株) のアミノ酸自動分析システム （LC-6 A）にて分析した ${ }^{13)}$ ．採血後，各臟器を摘出し て重量を測定した。

\section{6. 実験結果の検定}

実験結果は平均值土標準誤差で表した．各実験グルー プ間の有意差は分散分析による検定後 Student testにより検定し，有意水準は $5 \%$ 以下とした。

\section{実験結果および考察}

\section{1. 実験飼料の各形隹別窒素分布}

実験 1 および 2 で使用した実験飼料の総窒素量，水溶 性窒素, ペプチド・アミノ態窒素および遊離アミノ酸組 成を Table 2 に示した，実験 1 では，総堂素量は各群

Table 2 Nitrogen distribution and free amino acid contents of experimental diet

$(\mathrm{mg} / 100 \mathrm{~g})$

\begin{tabular}{|c|c|c|c|c|c|c|c|c|}
\hline & \multicolumn{4}{|c|}{ Exp. 1} & \multicolumn{4}{|c|}{ Exp. 2} \\
\hline & MP & $\mathrm{PE}$ & TR & PA & MP & $0.1 \mathrm{PA}$ & $2.0 \mathrm{PA}$ & $\mathrm{AA}$ \\
\hline $\begin{array}{l}\text { Total-N } \\
\text { (nitrogen) }\end{array}$ & 3296 & 3296 & 3456 & 3328 & 1664 & 1688 & 1688 & 1664 \\
\hline $\begin{array}{l}\text { Water solbule } \\
\text { protein-N }\end{array}$ & 484 & 520 & 937 & 2040 & 243 & 959 & 1617 & 1644 \\
\hline Peptide, Amino-N & 470 & 484 & 720 & 1770 & 238 & 898 & 1540 & 1644 \\
\hline Amino-N & 226 & 307 & 607 & 1039 & 112 & 520 & 888 & 1644 \\
\hline \multicolumn{9}{|l|}{ Free amino acids } \\
\hline Asp & 1.7 & 2.1 & 6.1 & 12.4 & 0.8 & 6.3 & 10.7 & 157.4 \\
\hline Thr & 11.8 & 20.1 & 40.2 & 74.4 & 6.0 & 38.8 & 65.2 & 74.4 \\
\hline Ser & 7.2 & 13.1 & 30.5 & 53.6 & 3.6 & 25.7 & 42.9 & 56.6 \\
\hline Glu & 15.4 & 24.3 & 55.6 & 81.5 & 7.6 & 41.0 & 70.7 & 244.2 \\
\hline Pro & 3.8 & 8.9 & 15.9 & 29.2 & 2.0 & 15.1 & 24.7 & 74.4 \\
\hline Gly & 8. 6 & 11.4 & 19.9 & 35.1 & 4.3 & 17.3 & 27.4 & 87.5 \\
\hline Ala & 18. 0 & 26.3 & 54.3 & 97.7 & 9.2 & 48.8 & 82.9 & 100.9 \\
\hline Val & 5.4 & 11.1 & 25.4 & 37.1 & 2.8 & 18.2 & 30.3 & 88.5 \\
\hline Met & 5.0 & 7.9 & 21.1 & 56.2 & 2.5 & 26.7 & 47.9 & 52.8 \\
\hline Ile & 5.2 & 10.2 & 27.1 & 50.2 & 2.8 & 24.8 & 44.6 & 83.9 \\
\hline Leu & 9.5 & 18.4 & 54.7 & 130.9 & 4. 7 & 63.2 & 108.8 & 130.4 \\
\hline Tyr & 6.9 & 11.6 & 27.3 & 56.0 & 3. 8 & 27.7 & 47.1 & 55.1 \\
\hline Phe & 6.0 & 13. 1 & 27.5 & 68.2 & 3.2 & 35.0 & 61.5 & 67.6 \\
\hline His & 107.7 & 118. 2 & 123.3 & 135.8 & 56.0 & 68.3 & 113.2 & 113.6 \\
\hline Lys & 5.3 & 10.0 & 35.1 & 62.6 & 2.7 & 33.1 & 56. 3 & 138.4 \\
\hline $\mathrm{NH}_{3}$ & 2.9 & 2.7 & 3.5 & 7.1 & 1.4 & 3.6 & 6.7 & 18.4 \\
\hline Arg & 5.9 & 13. 1 & 39.9 & 51.0 & 2.9 & 26.8 & 46.6 & 99.9 \\
\hline
\end{tabular}

MP : Defatted pork meat, PE : Pepsin hydroryzed pork meat, TR: Trypsin hydrolyzed pork meat, PA : Papain hydrolyzed pork meat, 0.1 PA : 0.1\% papain hydrolyzed pork meat, 2.0 PA: $2.0 \%$ papain hydrolyzed pork meat, AA : Amino acids mixture 
ともほぼ一緒であるのに対して，水溶性窒素，ペプチド ・アミノ態窒素, 遊離アミノ酸は未処理豚肉に比較して 各酵素加水分解物群では增加していた，酵素量は予め力 ゼインを基質として $50 \mathrm{I} . \mathrm{U} / \mathrm{g}$ と決めたが，末処理豚肉 に対する活性はパパインが最む高く，次いでトリプシン， ペプシンの順であった．パパインは従来より食肉の軟化 醉として利用されており ${ }^{14)}$ ，豚肉に対する活性が高く， 基質特異性の違いなどから酵素によって加水分解の程度 が異なったものと考えられる。実験 2 では飼料のタンパ ク質含有量が実験 1 の半分になっており，パパインの添 加量の增加に伴い低分子化は促進され，2.0\% 添加で大 部分のタンパク質は可溶化し，全堂素のほぼ $90 \%$ がぺ プチド・アミノ態窒素となっていた．これに対して，塩 酸加水分解では全窒素がアミノ酸で，これが豚肉の構成 アミノ酸であるものと考えられる，遊離アミノ酸に関し
ても，アスパラギン酸,グルタミン酸では $2.0 \%$ 酵菜好 理の值が塩酸加水分解での值より極端に小さいのに対し て，ロイシン，ヒスチジン等では同程度の数值であった， これは豚肉に対するパパインの基質特異性によるものと 考えられ，この酵素処理で充分遊離してくるアミ，酸と， ほとんよ゙遊離しないアミノ酸があることが明らかとなっ た.

\section{2. 体重增加量，飼料摄取量，飼料効率およひ肝臟重}

Table 3 に体重増加量, 飼料摄取量, 飼料効率およ び肝歲重量を示した．実験 1 ではパパイン処理豚肉摄取 群の体重が，他群に比べ增加傾向にあった．特にトリプ シン処理豚肉摂取群に対しては有意な増加を示した。 飼 料摂取量，飼料効率には全く差はみられなかった，実験 2 については，酸加水分解物摂取群の体重増加が有意に

Table 3 Body weight gain, food intake, food efficiency and liver weight in rats fed on the experimental diets

\begin{tabular}{|c|c|c|c|c|c|c|}
\hline \multirow{2}{*}{ Group } & \multirow{2}{*}{$\mathrm{n}$} & \multicolumn{2}{|c|}{ Body weight (g) } & \multirow{2}{*}{$\begin{array}{l}\text { Food intake } \\
(\mathrm{g} / \text { day })\end{array}$} & \multirow{2}{*}{$\begin{array}{l}\text { Food } \\
\text { efficiency }\end{array}$} & \multirow{2}{*}{$\begin{array}{l}\text { Liver weight } \\
\text { (\% of body weight) }\end{array}$} \\
\hline & & Initial & Gain & & & \\
\hline \multicolumn{7}{|l|}{ Exp. $1^{*}$} \\
\hline MP & 5 & $124 \pm 4$ & $95 \pm 7$ & $17.0 \pm 2.4$ & $0.27 \pm 0.02$ & $3.9 \pm 0.2$ \\
\hline $\mathrm{PE}$ & 5 & $124 \pm 6$ & $96 \pm 3$ & $16.8 \pm 2.8$ & $0.27 \pm 0.01$ & $3.7 \pm 0.1$ \\
\hline $\mathrm{TR}$ & 5 & $124 \pm 6$ & $91 \pm 4^{\mathbf{a}}$ & $16.9 \pm 2.4$ & $0.26 \pm 0.01$ & $3.4 \pm 0.2$ \\
\hline PA & 5 & $124 \pm 6$ & $102 \pm 10^{\mathrm{b}}$ & $18.0 \pm 2.9$ & $0.27 \pm 0.01$ & $3.4 \pm 0.2$ \\
\hline \multicolumn{7}{|l|}{$\operatorname{Exp} .2^{* *}$} \\
\hline $\mathrm{MP}$ & 5 & $112 \pm 6$ & $69 \pm 8^{a}$ & $13.9 \pm 3.1$ & $0.24 \pm 0.03$ & $2.8 \pm 0.1$ \\
\hline $0.1 \mathrm{PA}$ & 5 & $113 \pm 6$ & $70 \pm 4^{\mathrm{a}}$ & $13.8 \pm 3.0$ & $0.24 \pm 0.02$ & $2.7 \pm 0.1$ \\
\hline $2.0 \mathrm{PA}$ & 5 & $116 \pm 7$ & $71 \pm 5^{a}$ & $14.3 \pm 3.7$ & $0.24 \pm 0.02$ & $2.6 \pm 0.1$ \\
\hline AA & 5 & $115 \pm 7$ & $54 \pm 2^{b}$ & $12.5 \pm 3.2$ & $0.21 \pm 0.01$ & $2.9 \pm 0.1$ \\
\hline \multicolumn{7}{|l|}{ Exp. $3^{* * *}$} \\
\hline $\mathrm{MP}$ & 5 & $95 \pm 5$ & $87 \pm 8^{b}$ & $11.7 \pm 3.5$ & $0.39 \pm 0.03^{\mathrm{b}}$ & 4. $6 \pm 0.4$ \\
\hline $\mathrm{PA}$ & 5 & $97 \pm 4$ & $79 \pm 5^{b}$ & 11. $4 \pm 2.1$ & $0.36 \pm 0.02^{\mathrm{b}}$ & $4.6 \pm 0.6$ \\
\hline SOY & 5 & $91 \pm 4$ & $27 \pm 4^{\mathrm{a}}$ & $11.5 \pm 2.2$ & $0.12 \pm 0.02^{a}$ & 4. $3 \pm 0.2$ \\
\hline
\end{tabular}

Each value represents the mean \pm S.E.

* Exp. 1 : MP : Deffated pork meat, PE : Pepsin hydolyzed pork meat, TR : Trypsin hydrolyzed pork meat, PA : Papain hydrolyzed pork meat. The protein level of $20 \%$ was employed.

** Exp. 2 : MP : Deffated pork meat, $0.1 \mathrm{PA}: 0.1 \%$ papain hydrolyzed pork meat, 2.0 PA: $2.0 \%$ papain hydrolyzed pork meat, AA: Amino acids mixture. The protein level of $10 \%$ was employed.

*** Exp. 3 : MP : Deffated pork meat, PA : Papain hydrolyzed pork, SOY : Soybean protein. The protein level of $10 \%$ was employed.

a, $b$ In each experiment, values in the same column not sharing a common superscript letter are significantly different $; p<0.05$. 
劣っており，飼料摂取量，飼料効率についてあ低い傾向 がみられた。これは，膜消化による消化吸収性の違いを 反映しているのかも知れない垃．奏験 3 では大豆タンパ ク質摄取群の体重増加量, 飼料効率が未処理豚肉摄取群, 酵素処理豚肉摄取群に比べて有意に低くなった。

\section{3. 血漿脂質成分分析}

Table 4 に血漿中の総 chol，遊離 chol，トリグル セリド扔よびリン脂質濃度を示した、実験 1 では総 chol, 遊離 chol, トリグリセリドおよびリン脂質の全 てで未好理豚肉摂取群に比べて，各酵素処理群で低下す る傾向がみられた．特に興味深いことに，植物由来の酵 素であるパパイン処理豚肉摄取群では各脂質成分で有意 に低值となっていた。また実験 2 では総 chol, トリグ リセリドが，パパイン添加量に応じて低下し，全窒素の
90\% が低分子化していた $2.0 \%$ パパイン処理群では末 処理豚肉摂取群に比べて総 chol 值は $40 \%$ すの堿少を 示した. またトリグリセリドについても全く同様に極端 な低下を示していた，しかし，酸加水分解物摂取群では 各脂質成分の低下はみられず $2.0 \%$ パパイン処理群と比 較して有意に高值となった．実験 3 でも同様に末処理豚 肉摄取群に比べて，酵素処理豚肉摂取群では各脂質成分 が低下していた．絵 chol については大豆タンパク質摂 取群は末処理豚肉提取群, 醉素処理豚肉摄取群よりも有 意に低下していた。

\section{4. 血漿リポタンパク質 chol 渻度}

Table 5 に実験 2 での血墏リポタンパク質の総 chol 濃度を示した。 chol 代謝に関して, リポタンパク質レ ベルでの変化は重要であり，動物種，飼育条件によって

Table 4 Concentration of plasma total cholesterol, free cholesterol, triglyceride and phospholipid

\begin{tabular}{ccccc}
\hline \hline & $\begin{array}{c}\text { Total } \\
\text { cholesterol }\end{array}$ & $\begin{array}{c}\text { Free } \\
\text { cholesterol }\end{array}$ & Triglyceride & Phospholipid \\
\hline Exp. $1^{*}$ & & & & \\
MP & $226 \pm 9^{\mathrm{a}}$ & $29.8 \pm 1.0^{\mathrm{a}}$ & $89.1 \pm 2.4^{\mathrm{a}}$ & $162 \pm 4^{\mathrm{a}}$ \\
PE & $215 \pm 8^{\mathrm{a}}$ & $25.5 \pm 1.2^{\mathrm{b}}$ & $86.3 \pm 1.6^{\mathrm{a}}$ & $146 \pm 5^{\mathrm{b}}$ \\
TR & $209 \pm 8^{\mathrm{a} b}$ & $23.0 \pm 0.7^{\mathrm{b}}$ & $86.6 \pm 2.2^{\mathrm{a}}$ & $143 \pm 4^{\mathrm{b}}$ \\
PA & $192 \pm 11^{\mathrm{b}}$ & $22.3 \pm 1.0^{\mathrm{b}}$ & $77.2 \pm 2.1^{\mathrm{b}}$ & $132 \pm 3^{\mathrm{c}}$ \\
\hline Exp. $2^{* *}$ & & & & \\
MP & $188 \pm 11^{\mathrm{a}}$ & $32.6 \pm 2.9^{\mathrm{a}}$ & $78.8 \pm 1.8^{\mathrm{a}}$ & $164 \pm 7$ \\
0.1 PA & $152 \pm 6^{\mathrm{b}}$ & $27.8 \pm 1.6^{\mathrm{b}}$ & $52.8 \pm 1.2^{\mathrm{b}}$ & $154 \pm 6$ \\
2.0 PA & $110 \pm 5^{\mathrm{c}}$ & $21.9 \pm 1.7^{\mathrm{c}}$ & $40.0 \pm 1.9^{\mathrm{c}}$ & $156 \pm 7$ \\
AA & $180 \pm 4^{\mathrm{a}}$ & $30.8 \pm 0.9^{\mathrm{a}}$ & $73.2 \pm 2.6^{\mathrm{a}}$ & $159 \pm 7$ \\
\hline Exp. 3 & & & \\
MP & $199 \pm 6^{\mathrm{a}}$ & $33.8 \pm 3.5^{\mathrm{a}}$ & $63.9 \pm 3.4^{\mathrm{a}}$ & $188 \pm 10^{\mathrm{a}}$ \\
PA & $155 \pm 9^{\mathrm{b}}$ & $21.3 \pm 3.2^{\mathrm{b}}$ & $53.3 \pm 1.4^{\mathrm{b}}$ & $173 \pm 6^{\mathrm{a}}$ \\
SOY & $129 \pm 11^{\mathrm{c}}$ & $18.2 \pm 2.1^{\mathrm{c}}$ & $42.9 \pm 2.8^{\mathrm{c}}$ & $155 \pm 8^{\mathrm{b}}$ \\
\hline
\end{tabular}

Each value represents the mean \pm S.E. of five rats.

* Exp. 1 : MP : Deffated pork meat, PE : Pepsin hydolyzed pork meat, TR : Trypsin hydrolyzed pork meat, PA : Papain hydrolyzed pork meat. The protein level of $20 \%$ was employed.

** Exp. 2 : MP : Deffated pork meat, 0.1 PA : 0.1\% papain hydrolyzed pork meat, 2.0 PA : 2.0\% papain hydrolyzed pork meat, AA: Amino acids mixture. The protein level of $10 \%$ was employed.

*** Exp. 3: MP : Deffated pork meat, PA : Papain hydrolyzed pork, SOY : Soybean protein. The protein level of $10 \%$ was employed.

$a, b, c$ In each experiment, values in the same column not sharing a common superscript letter are significantly different $; p<0.05$. 
Table 5 Total cholesterol concentration of plasma lipoprotein (Exp. 2)

\begin{tabular}{lccccc}
\hline \hline Group & Chylomicron & VLDL & LDL & HDL & Total \\
\hline MP & $42.3 \pm 3.0^{\mathrm{a}}$ & $18.9 \pm 1.1^{\mathrm{a}}$ & $39.9 \pm 2.4^{\mathrm{a}}$ & $56.3 \pm 2.5^{\mathrm{a}}$ & 157 \\
$0.1 \mathrm{PA}$ & $37.8 \pm 1.9^{\mathrm{b}}$ & $17.7 \pm 1.1^{\mathrm{a}}$ & $37.2 \pm 1.0^{\mathrm{a}}$ & $51.1 \pm 1.5^{\mathrm{a}}$ & 144 \\
2.0 PA & $21.9 \pm 1.9^{\mathrm{c}}$ & $14.1 \pm 1.3^{\mathrm{b}}$ & $28.4 \pm 1.2^{\mathrm{b}}$ & $40.6 \pm 1.4^{\mathrm{b}}$ & 105 \\
AA & $34.6 \pm 2.0^{\mathrm{b}}$ & $14.7 \pm 0.4^{\mathrm{b}}$ & $30.6 \pm 1.7^{\mathrm{b}}$ & $63.2 \pm 1.1^{\mathrm{c}}$ & 143 \\
\hline
\end{tabular}

Each value represents the mean \pm S.E. of five rats.

$(\mathrm{mg} / \mathrm{d} l)$

MP : Deffated pork meat, 0.1 PA : 0.1\% papain hydrolyzed pork meat, 2.0 PA : 2.0

$\%$ papain hydrolyzed pork meat, AA : Amino acids mixture.

The protein level of $10 \%$ was employed.

${ }^{a, b, c}$ In each experiment, values in the same column not sharing a common superscript letter are significantly different ; $\mathrm{p}<0.05$.

異なるものの，大豆タンパク質摄取によって起こる血清 chol 及び LDL-chol の低下は VLDL-chol の低下に よるすのであると報告されている(6). 本実験の結果から， 総 chol については豚肉タンパク質加水分解物の摂取に よる血漿 chol の低下と同調して, VLDL, LDL, HDL で chol は均等に低下しており, VLDL-cholや LDL-chol が特に低下する様子は観察されなかった。 しかし，酸加水分解物摄取群は VDL，LDL は低下し ているが，反対に HDLは上昇していた.

\section{5. 血漿中の遊離アミノ酸分析}

Fig. 1，2 に実験 2 及び 3 での，血漿中遊離アミノ酸 の濃度を示した．実験 3 ではメチオニン・ヒスチジン等 の必須了ミノ酸は，大豆タンパク質摄取群に比べて未処 理豚肉摄取群で有意に多くなっているが，反対にグル夕 ミン酸は大豆タンパク質摄取群で多くなっていた，さら に興味深いことに酵素処理豚肉摄取群では血漿中のメチ オ二ン浱度が減少し，遊離了ミノ酸組成が未処理豚肉摄 取群より，大豆タンパク質撕取群に類似してきた。 また 実験 2 からあ醉素添加量を增加することにより，遊離グ ルタミン酸が増加し，メチオニンが隇少した．木村らは 大豆タンパク質と豚肉タンパク質を摂取した場合の血漿 中の遊離了ミノ酸組成について検討した結果, 必須了ミ ノ酸は豚肉摄取により有意に多くなるが，反対にグル夕 ミン酸は大豆タンパク質摄取時により多くなることを報 告している ${ }^{17}$. また，杉山らはカゼインを用いた高 chol 食に脂肪としてラードを用いた場合にメチオニン を添加することにより，血墏 chol が著しく上昇するこ 之を示し ${ }^{18}$ ，食眲中のメチニオンが血墏 chol 上昇効果 を増幅させることを報告した。

タンパク質の血清・血整 chol に及ぼす影響について
は，大豆タンパク質やカゼインを用いた実験があり ${ }^{2)}$, 一般に大豆タンパク質摄取は動物性タンパク質摄取時に 比べて，血墏 chol 濃度は低く ${ }^{3)}$, これはタンパク質の 構成了ミノ酸組成，特にリシンン/アルギニンの比率に依 存すると考元られている゙．大豆タンパク質のペプシン 加水分解物がインタクトな大豆タンパク質に比べて更に 血清 chol を低下させるということは確認されていない が ${ }^{199}$ ，加水分解物を各成分に分画した場合に不溶性高分 子画分が非常に強い血清 chol 上昇抑制効果を有する之 報告されている ${ }^{910)}$. 一方, 動物タンパク質であるカぜ インについては，その醉素加水分解物はインタクトなカ ゼインと同様に，大豆タンパク質を摄取した場合に比べ て高值の血清 chol 濃度を与えると考えられている20.

しかし，カゼインの部分加水分解物が chol 溚度の上昇 を抑制するとの報告す見られ，その効果は明確ではな

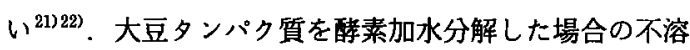
性高分子画分の chol 上昇抑制効果の機序については疎 水性ペプチドが胆汁酸之結合し，䔬便中への中性・酸性 ステロイド排泄量を增加させることにより，血清 chol 濃度を低下させるあのと考えられている年年23). 今回の 実験では，パパイン加水分解物と豚肉の構成アミ/酸組 成に相違は見られなかったことと，パパイン添加量を增 加させてペプチド・アミノ態窒素が増加するに従って, 血獎 chol 濃度が更に低下し，また完全にアミノ酸の混 合物である酸加水分解物では効果が見られなかったこと から，その抑制効果は構成アミ／酸によるものではなく， ペプチドに由来していると考えられた，また，実験 2 の 各飼料において, 含硫了ミ/酸の量やリジン/アルギニ ン比に差の見られなかったことから豚肉醉素処理物の血 鼎 $\mathrm{chol}$ 上昇抑制効果は特定のアミノ酸によるあのでは 

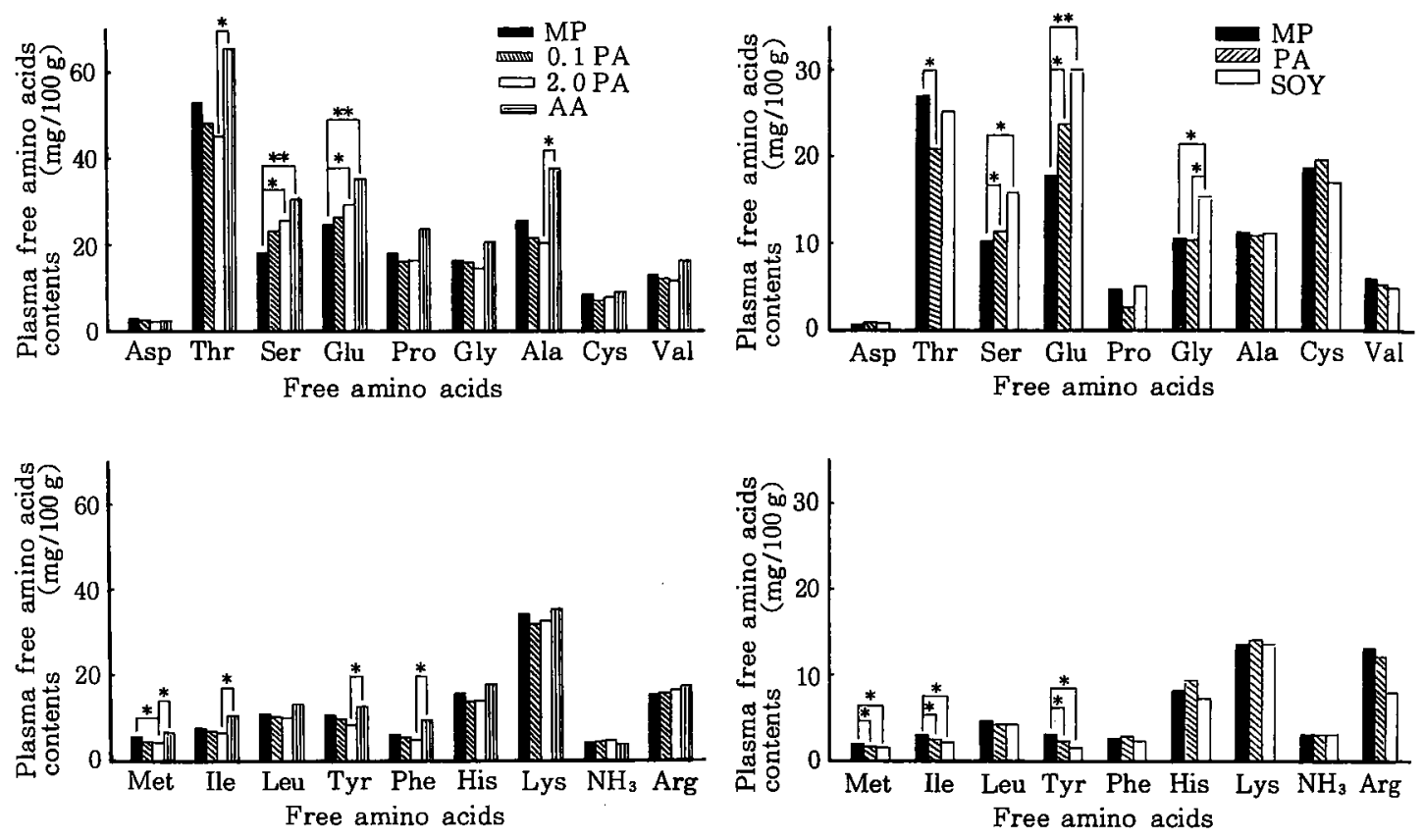

Fig. 1 Free amino acids contents in plasma (Exp. 2)

MP : Defatted pork meat, 0.1 PA : $0.1 \%$ papain hydrolyzed pork meat, 2.0 PA : 2.0 $\%$ papain hydrolyzed pork meat, AA: Amino acids mixture

${ }^{*},{ }^{* *}$ : Significantly different at $\mathrm{p}<0.05$, $\mathrm{p}<0.01$

なく，大豆タンパク質加水分解物と同様に消化管内での ペプチドの作用による可能性が推測された. 今後摄取 chol の吸収量及び翼中への chol, 胆汁酸の排泄量む合 わせて検討する必要があると考えられた．しかし，豚肉 タンパク質の酵素加水分解物摄取時には未処理豚肉摂取 時に比べて，血中のメチオニン濃度が低下する事から特 定のアミノ酸による影響む検討する必要があると思われ た.

\section{要 約}

豚肉の酵素加水分解物の血獎 chol 上昇抑制効果につ いてラットを用いて検討し, 次の結果が得られた。

（1）豚肉のパパイン加水分解物は，豚肉に比べて血將 chol 濃度の上昇を抑制した。

（2）パパインの添加量を増加させ，ペプチドの産出が

Fig. 2 Free amino acids contents in plasma (Exp. 3)

MP : Defatted pork meat, PA : Papain hydrolyzed pork meat, SOY: Soybean protein

${ }^{*},{ }^{* *}$ : Significantly different at $\mathrm{p}<0.05$, $\mathrm{p}<0.01$

多くなるほど血嶈 chol 濃度は抑制された。しかし，完 全了ミ/酸湿合物を想定した酸加水分解物ではその効果 は見られなかった．これらのことから，豚肉の醉素加水 分解物の血漿 chol 上昇抑制効果はペプチドによるもの と考えられた。

(3) 酵素処理豚肉摂取時に，血睩リポタンパク質の chol に特徴的な変動は見られず，血觜遊離アミノ酸に ついては大豆タンパク質摄取時と類似してきた。

(4) これらのことから，畜肉製品において，今までに 血策 chol 濃度上昇牒制効果を有することが報告されて きた大豆タンバク質や食物䄉維などの添加物を使用する ことなく，畜肉原料のみで血漿 chol の上昇抑制効果の ある食肉加工品を作り得る可能性が示唆された。

本研究の概要は， 1991 年 5 月，第 45 回日本栄養・食 糧学会総会 (京都市) にて発表した。 


\section{文献}

1) Lipid Research Clinic Program, JAMA, 251, 351, 365 (1984).

2) HuFr, M.W., Hamilton, R.M.G. and CARroll, K.K. : Adv. Exp. Biol. Med., 275, 82 (1975).

3) Carroll, K.K. : Nutr. Rev., 36, 2 (1977).

4) Gibney, M.J.: Proc. Nutr. Soc. 41, 19 (1978).

5）菅野道廣：米・大豆と魚，藤巻正生・井上五郎・ 田中武彦編（光生館）, p. 100 (1984).

6) Huff, M.W. and Carroll, K,K. : J. Nutr. 110, 1676 (1980).

7) Kritchevsky, D. and KluRfeld, D.M : $J$. Am. Oil Chem. Soc. 64, 8, 1167 (1985).

8）管野道腐・山田幸男・吉田克子：必須了ミ儿酸研 究, 116, 34 (1987).

9) Sugano, M., Yamada, Y., Yoshida, K., Hashimoto, Y., Matsuo, T. and Kimoto, M. : Atherosclerosis, 72, 115 (1988).

10) Sugano, M., Goto, S., Yamada, Y., Yoshida, K., Hashimoto, Y., Matsuo, T. and Kгмото, M. : J. Nutr, 120, 977 (1990).

11）高藤慎一: 雪印乳業研究所報告, 第 90 号 (1990).

12) Havel, R.J., Eder, H.A. and Bragdon, J.H. : J. Clin. Invest., 34, 1345 (1955).

13) Ishida, Y., Fujita, T. and Asai, K.: $J$. Chromatgr., 204, 16 (1981).
14）西尾重光：食肉研究会発表，4月（1965）.

15）内藤 博共著 : 新栄養化学 (朝倉書占), p. 148 (1987)

16) KluRfeld, D.M. and Kritchevsky, D. : ORY, R.l. (ed.) Plant Proteins : Applications, Biological Effects, and Chemistry (American Chemical Society, Washington, DC) , p, 150 (1986).

17) Kimura, S., Kim, C.H., Оhтomo, I.M., YokomukaI, Y., KomaI, M. and MorIMATSu, F. : Physiology and Behavior, 49, 997 (1991).

18）杉山公男: 栄食誌, 42, 5 (1989).

19) Sugano, M.: Gibney, M.J. and KritcHEvsky, D. (eds.) : Animal and Vegitable Proteins in Lipid Metabolism and Atherosclerosis (Alan R. Liss, New York), p. 51 (1983).

20) Huff, M.W., Hamilton, R.M.G. and Carroll, K.K.: Atherosclerosis, 28, 187 (1977).

21) Tanaka, C. and Nozaki, Y.: J. Nutr. Sci. Vitaminol, 29, 439 (1983).

22）菅野道廣・屋代彰子・小田 忍: 必須アミ/酸研 究, 106, 28 (1985).

23) Iwami, K., Sakakibara, K. and Ibuki F. : Agric. Biol. Chem., 50, 1217 (1986).

(平成 3 年 9 月 6 日受理) 